\title{
Glycated Hemoglobin and Methods for Its Point of Care Testing
}

\author{
Miroslav Pohanka (D)
}

Citation: Pohanka, M. Glycated Hemoglobin and Methods for Its Point of Care Testing. Biosensors 2021, 11, 70. https://doi.org/10.3390/ bios 11030070

Received: 11 February 2021

Accepted: 1 March 2021

Published: 4 March 2021

Publisher's Note: MDPI stays neutral with regard to jurisdictional claims in published maps and institutional affiliations.

Copyright: (C) 2021 by the author. Licensee MDPI, Basel, Switzerland. This article is an open access article distributed under the terms and conditions of the Creative Commons Attribution (CC BY) license (https:/ / creativecommons.org/licenses/by/ $4.0 /)$.
Faculty of Military Health Sciences, University of Defense, Trebesska 1575,

CZ-50001 Hradec Kralove, Czech Republic; miroslav.pohanka@gmail.com or miroslav.pohanka@unob.cz

\begin{abstract}
Glycated hemoglobin $\left(\mathrm{HbA}_{1 \mathrm{c}}\right)$ is a product of the spontaneous reaction between hemoglobin and elevated glucose levels in the blood. It is included among the so-called advanced glycation end products, of which is the most important for the clinical diagnosis of diabetes mellitus, and it can serve as an alternative to glycemia measurement. Compared to the diagnosis of diabetes mellitus by glycemia, the $\mathrm{HbA}_{1 \mathrm{c}}$ level is less influenced by a short-term problem with diabetes compensation. Mass spectroscopy and chromatographic techniques are among the standard methods of $\mathrm{HbA}_{1 \mathrm{c}}$ level measurement. Compared to glycemia measurement, there is lack of simple methods for diabetes mellitus diagnosis by means of the $\mathrm{HbA}_{1 \mathrm{c}}$ assay using a point-of-care test. This review article is focused on the surveying of facts about $\mathrm{HbA}_{1 \mathrm{c}}$ and its importance in diabetes mellitus diagnosis, and surveying standard methods and new methods suitable for the $\mathrm{HbA}_{1 \mathrm{c}}$ assay under point-of-care conditions. Various bioassays and biosensors are mentioned and their specifications are discussed.
\end{abstract}

Keywords: advanced glycation end products; analysis; bioanalysis; biosensor; chromatography; diabetes; diagnosis; glucose; hand held assay; lateral flow test; mass spectrometry

\section{Introduction}

Point-of-care testing has become a relevant part and aim of analytical and bioanalytical chemistry, and various target markers can be determined by these tests [1-8]. Although standard instrumental analyses, such as chromatography, mass spectrometric and electrophoretic analyses, have good potential to be used for the routine detection of biochemical, immunochemical and other markers, they are predetermined for laboratory use due to their complexity and costs. Simple methods for point-of-care diagnoses are available as well but they are typically suitable for simple markers and parameters (e.g., colorimetric clinical urine tests, electrochemical glucose tests). Some markers can be examined by colorimetric tests in the lateral flow immunochromatographic assay (e.g., pregnancy tests). In view of their complexity, many pathological processes and related diseases are not covered by adequate tests that are suitable for performance outside laboratories.

Glycated hemoglobin $\left(\mathrm{HbA}_{1 \mathrm{c}}\right)$ is an additional marker, besides the standard glucose and glycemia analyses, that has become a relevant marker in new analytical methods. As discussed below, the determination of $\mathrm{HbA}_{1 \mathrm{c}}$ is substantial for diabetes diagnosis and provides substantial results compared to the simple measurement of glycemia [9-11]. Point-of-care testing of $\mathrm{HbA}_{1 \mathrm{c}}$ appears to be a suitable approach to timely and accurately revealing diabetes mellitus and it demonstrates a better quality of diagnosis compared to the standard determination of glycemia [12-14].

In this study, simple methods like biosensors and hand-held bioassays are reviewed and their practical relevance considering analytical parameters is discussed in the context of the standard analytical approaches. The analytical methods are discussed in view of their applicability in point-of-care testing. A survey of the current literature is provided as well. 


\section{Glycated Hemoglobin and Other Advanced Glycation End-Products}

$\mathrm{HbA}_{1 \mathrm{c}}$ is a glucose-modified hemoglobin created during the spontaneous reaction between glucose and $\mathrm{N}$-terminal valine residues on $\beta$ chains of hemoglobin-creating $\beta$ $\mathrm{N}$-1-deoxy fructosyl [15]. The exact chemical mechanism of glycosylation is based on the formation of a Schiff base then shifting into rearrangement by means of Maillard reactions, eventually providing the final molecule with covalently bound glucose, called the Amadori product, or an advanced glycation end-product $[16,17]$. The principles of this chemical reaction are depicted in Figure 1. Once $\mathrm{HbA}_{1 \mathrm{c}}$ is formed, it remains in the blood circulation for quite a long time, typically from two to three months, because of the lifespan of erythrocytes, which is approximately 120 days [18]. The blood level of $\mathrm{Hb}_{1 \mathrm{c}}$ is quite stable and not sensitive to time of day, fasting or recently taken food [19]. All the aforementioned facts make $\mathrm{HbA}_{1 \mathrm{c}}$ a good marker for diabetes mellitus, with minimal misdiagnosis due to temporary and non-pathological changes in glycemia [20,21]. Though the measuring of $\mathrm{HbA}_{1 \mathrm{c}}$ is commonly considered a good way to diagnose diabetes mellitus, some pathologies like hemolytic anemia, which affects the lifespan of erythrocytes, or the presence of an abnormal chain in the hemoglobin molecule, can cause the distortion of results [22].

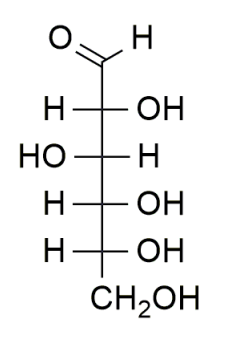

D-glucose

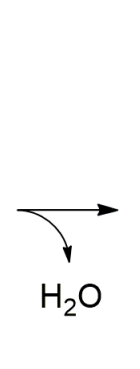

Schiff base<smiles>O=C(CNP)C(O)C(O)C(O)CO</smiles>

Amadori product

Figure 1. Chemical principles of hemoglobin glycation, $\mathrm{Hb}=$ hemoglobin.

Hemoglobin is not the only protein providing advanced glycation end-products. The same mechanism happens for the other proteins located in the blood system, but their diagnostic meaning is less significant compared to the $\mathrm{HbA}_{1 \mathrm{c}}$. Glycated albumin may be mentioned as an important example. The blood or plasma level of glycated albumin is influenced by a time span of approximately two to three weeks [23], corresponding with the expected half-life of albumin, 15-20 days [18]. The glycosylation of albumin is dominantly made through lysine or less commonly by arginine [24]. The diagnostic meaning of glycated albumin is nearly the same as that of $\mathrm{HbA}_{1 \mathrm{c}}[25,26]$. Although the glycated albumin level is not influenced by hemoglobin disorders, there can be changes in its blood concentration due to disorders in albumin metabolism like nephrotic syndrome, hyper- or hypothyroidism or liver cirrhosis [27]. When proteins become glycated, they also change in terms of their conformation and surface hydrophobicity compared to non-glycated structures [28-30]. The molecular weight of hemoglobin $-64.5 \mathrm{kDa}$ with one bound glucose at the most—can rise to $68 \mathrm{kDa}$ when up to 15 glucose moieties are attached [31,32]. Fluorescence intensity can rise as well, from $34 \%$ for non-glycated hemoglobin up to $45 \%$ for $\mathrm{HbA}_{1 \mathrm{c}}$ [30]. Therefore, fluorescence can serve as an assay for the identification of hemoglobin types [33]. Raman spectroscopy can distinguish the types of hemoglobin as well [34]. The changes in surface hydrophobicity can be studied by reagents like 6-p-toluidinylnaphtalene-2-sulfonate and 8-anilinonaphtalene-1-sulfonate, providing fluorescence depending on the polarity of the solvent, developing low fluorescence in polar solvents (like water) and high fluorescence in low-polarity solvents $[35,36]$. Glycation of hemoglobin make $\mathrm{HbA}_{1 \mathrm{c}}$ less polar than the non-glycated hemoglobin, which can be visualized by 8-anilinonaphtalene-1-sulfonate [30]. Glycation of albumin leads to a slight increase in polarity, making it visible by the addition of a 6-p-toluidinylnaphtalene-2-sulfonate molecule [35]. The surface hydrophobic areas can serve for retention of the whole molecule during chromatographic isolation. For 
instance, hemoglobin was separated in a polar-phase system and showed a high value of the partition coefficient in a more hydrophobic environment such as polyethylene glycol polymer enriched with oleate [37]. Normal and elevated glycated hemoglobin were distinguished between phases composed of various amounts of PEG 600, Dextran 500 or polyvinylpyrrolidone. Researchers used polar phases and successfully distinguished levels of glycated hemoglobin indicated by the polar character of the surface $[38,39]$.

The ratio of $\mathrm{HbA}_{1 \mathrm{c}}$ vs. the non-glycated hemoglobin serves for the diagnosis of diabetes mellitus. Healthy people have less than approximately $42 \mathrm{mmol} / \mathrm{mol}$ of $\mathrm{HbA}_{1 \mathrm{c}}$ compared to the total hemoglobin, representing $6.0 \%$. Suspected diabetes mellitus (prediabetes) lies in the range of $42-47 \mathrm{mmol} / \mathrm{mol}$, respectively, representing $6.0 \%$ to $6.4 \%$. The presence of $\mathrm{HbA}_{1 \mathrm{c}}$ above the value of $48 \mathrm{mmol} / \mathrm{mol}$, representing $6.5 \%$ and over, is typical for people suffering from diabetes mellitus [40,41]. The comparison of non-glycated hemoglobin and $\mathrm{HbA}_{1 \mathrm{c}}$ is presented in Table 1.

Table 1. Basic specifications of non-glycated hemoglobin and $\mathrm{HbA}_{1 \mathrm{c}}$.

\begin{tabular}{cccc}
\hline Specification & $\begin{array}{c}\text { Non-Glycated } \\
\text { Hemoglobin }\end{array}$ & HbA $_{\mathbf{1 c}}$ & References \\
\hline Number of glycated sites/molecular weight & $1 / 64.5 \mathrm{kDa}$ & $15 / 68 \mathrm{kDa}$ & {$[31,32]$} \\
Florescence intensity & $34 \%$ & $45 \%$ & {$[30]$} \\
Hydrophobicity & high & low & {$[38,39]$} \\
Percentage in blood of health people & above $94 \%$ & under 6.0\% & {$[40,41]$} \\
Percentage in blood of people & $94.0-93.5 \%$ & $6.0-6.5 \%$ & {$[40,41]$} \\
$\begin{array}{c}\text { with prediabetes } \\
\text { Percentage in blood of people with } \\
\text { diabetes mellitus }\end{array}$ & under 93.5\% & above 6.5\% & {$[40,41]$} \\
\hline
\end{tabular}

\section{Standard Methods for Glycated Hemoglobin Assay}

Instrumental analytical methods serve as the standard tools for both recognizing new cases of diabetes mellitus and controlling whether the diagnosed diabetes mellitus is adequately compensated for [42]. In general, assays should be focused on distinguishing the standard hemoglobin and $\mathrm{HbA}_{1 \mathrm{c}}$. Physical and chemical differences between the two molecules serve the assay's purpose. Interaction with antibodies creates the opportunity to distinguish the both types of hemoglobin by means of an immunoassay, different physical properties of the molecule surface (mainly due to surface polarity) allow isolation and determination by means of chromatography and the different weights of molecules and their fragments are the premise of mass spectrometry (MS). The general principles of the $\mathrm{HbA}_{1 \mathrm{c}}$ assay in the presence of standard hemoglobin are summarized in Figure 2.
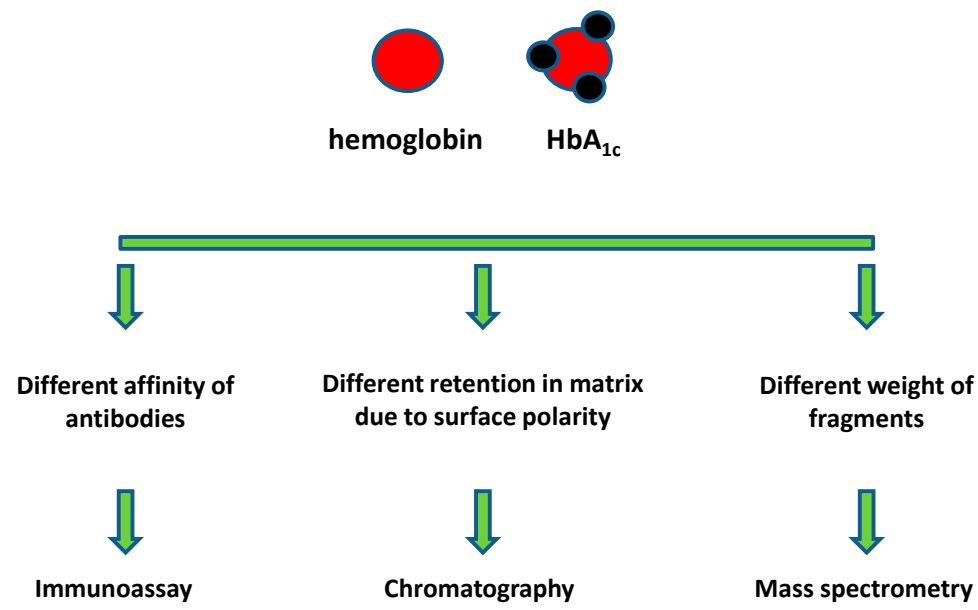

Figure 2. General principle of $\mathrm{HbA}_{1 \mathrm{c}}$ assay in the presence of standard hemoglobin. 
Various chromatographic methods, spectrometric methods and their combination are common in the clinical praxis. High-performance liquid chromatography (HPLC) [43,44], cation exchange HPLC [45], Liquid chromatography (LC) tandem MS [46-48], matrixassisted laser desorption ionization time-of-flight MS [49], capillary electrophoresis [50,51] and capillary zone electrophoresis tandem MS [52,53] can be mentioned as suitable for distinguishing between hemoglobin types. Immunochemical methods like the precipitationturbidimetric method [50], fluorometric immunoassays [54] and the enzyme-linked immunosorbent assay (ELISA) [55-57] are also suitable for $\mathrm{HbA}_{1 \mathrm{c}}$ measurement.

The aforementioned instrumental analyses provide robust data about $\mathrm{HbA}_{1 \mathrm{c}}$ respectively to non-glycated hemoglobin. Though the analytical properties of the described methods are good enough to cover the expected ranges of $\mathrm{HbA}_{1 \mathrm{c}}$ compared to non-glycated hemoglobin, they are not suitable for performance outside equipped laboratories and their use requires educated laboratory staff. Apart from instrumental analyses, no fully applicable assay is available for point-of-care testing, despite the fact that such methods are highly desired and would improve the effectiveness of care for diabetes mellitus suffering patients. On the other hand, the instrumental analyses have become smaller and cheaper in recent years. Despite their limited application potential for point-of-care testing, better availability of instrumental analyses could be relevant for small laboratories, mobile hospitals, etc. Nevertheless, future research is expected to examine both directions: standard instrumental analyses and point-of-care tests.

\section{Biosensors and Bioassays Measuring $\mathrm{HbA}_{1 \mathrm{c}}$}

Handheld assays and tests, like various biosensors, hand-held bioassay test kits and similar analytical devices, could allow clinicians to make a diagnosis of diabetes mellitus in home conditions or conditions of small laboratories and private medical practices. They are not considered to be a replacement of the standard instrumental analytical methods, but biosensors and bioassays should be considered as a replenishment of the available set of methods, creating the opportunity to perform point-of-care tests. It is expected that biosensors and hand-held bioassays will be cheaper that the standard instrumental methods, will be applicable without expensive measuring or sample-processing devices and will require neither elaborative sample or reagents processing nor demands on staff training or education. Currently, there are methods and biosensors available for the rapid detection of glucose and glycemia level determination, and these devices exert good analytical parameters, simplicity and low costs, and noninvasive methods for measuring glucose have even been developed [58-66]. Though the methods for measuring glucose are promising and many of them are currently available in the market, they have limitations in the interpretation of glucose level, as discussed in the previous chapter.

Lateral flow immunochromatographic assays, also known as lateral flow tests, can be mentioned as a bioassay platform that would be applicable in point-of-care conditions. This assay works on the principle of analyte interaction with labeled (colored nanoparticles, fluorescence reagent, etc.) antibodies compared to other molecules exerting specific affinity. The analyte migrates by means of lateral flow and visible zones are formed by capturing either the analyte or the unreacted antibody by other recognition molecules (antibodies) that are immobilized on the thin-layer chromatography matrix. The general principle of the assay for $\mathrm{HbA}_{1 \mathrm{c}}$ is depicted in Figure 3. Various analytes including human chorionic gonadotropin (pregnancy test) and various antibodies and antigen markers can be measured by the lateral flow immunochromatographic assay and pregnancy tests can be mentioned as a common example of the actual use of these tests [67-69]. On the other hand, the lateral flow immunochromatographic assay provides a semiquantitative signal only and it is not fully applicable for the quantification of a marker, though there have been promising experiments aiming to make the assay suitable for the determination of exact concentrations [70]. The improved versions of lateral flow immunochromatographic assays can provide fully or partially quantified signals; on the other hand, instrumentation for color density, fluorescence intensity, Raman spectroscopy or other instrumentation is 
necessary in this case [71-75]. The use of instrumentation would make the lateral flow immunochromatographic assay more applicable for diabetes mellitus, but this also creates material demands on equipment and limits the ability to perform the lateral flow immunochromatographic assay in point-of-care conditions. In addition to the standard lateral flow tests, various microfluidic devices have become popular and applicable in practice [76-79].

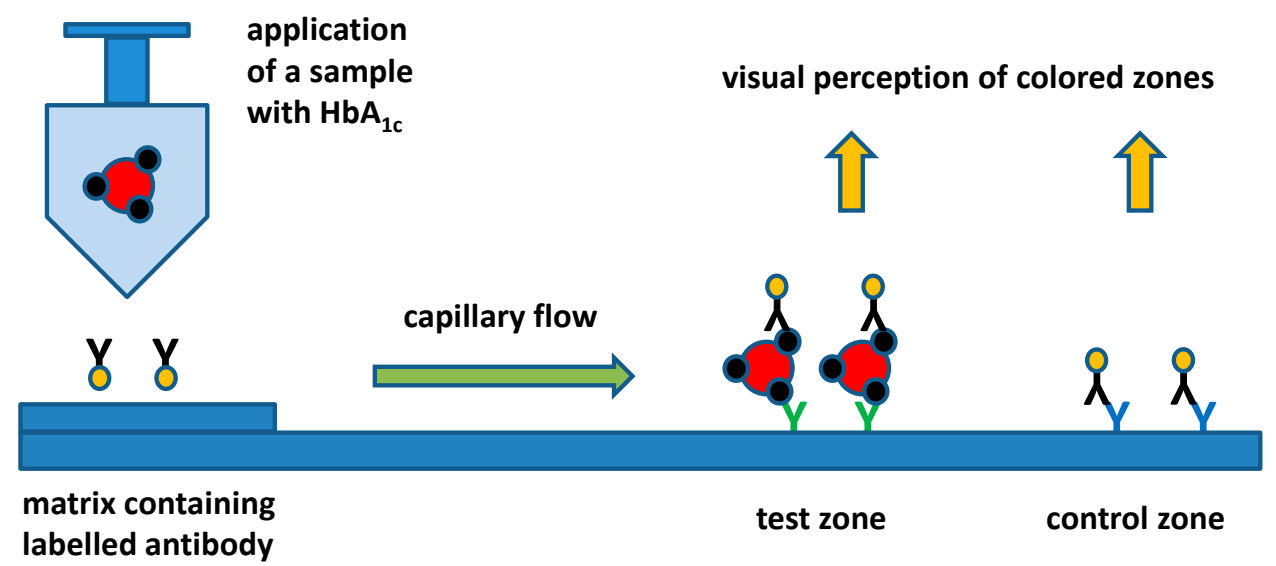

Figure 3. General principle of lateral flow test for $\mathrm{HbA}_{1 \mathrm{c}}$ assay.

In recent years, there has been great progress in the construction of biosensors and similar methods for the $\mathrm{HbA}_{1 \mathrm{c}}$ assay [80-90]. Various optical and electro-optical sensor methods have been developed in the past few years. A biosensor for the detection of $\mathrm{HbA}_{1 \mathrm{c}}$ was developed by Sun and coworkers using a surface plasmon resonance platform [91]. The researchers used an aptamer as the recognition part of the biosensor and were able to detect $\mathrm{HbA}_{1 \mathrm{c}}$ with a limit of detection of $2.55 \mathrm{nmol} / \mathrm{L}$ and a sensitivity of $1.06 \times 10^{-3} \mathrm{RU} / \mathrm{nmol} / \mathrm{L}$. In another work, surface plasmon resonance with an immobilized aptamer served for the measurement of $\mathrm{HbA}_{1 \mathrm{c}}$ with a limit of detection of $1 \mathrm{nmol} / \mathrm{L}$ and a linear dynamic range of 18-147 nmol/L [92]. An aptamer was also used in the work by Lin and coworkers [93]. The authors immobilized the aptamer on a bacteriorhodopsinembedded purple membrane as a physico-chemical transducer. The aptamer was specific against either $\mathrm{HbA}_{1 \mathrm{c}}$ or non-glycated hemoglobin. The interaction of aptamer with the $\mathrm{HbA}_{1 \mathrm{c}}$ or non-glycated hemoglobin reduced the detected photocurrent because of partial light absorption by the captured analyte. The assay exerted equal limits of detection for both types, under $0.1 \mu \mathrm{g} / \mathrm{mL}$, and a dynamic range of $0.1-100 \mu \mathrm{g} / \mathrm{mL}$ in a $15-\mathrm{min}$ measuring cycle. An electrochemiluminescence sensor was constructed for the measuring of $\mathrm{HbA}_{1 \mathrm{c}}$ using Tris(2,2'-bipyridyl)dichlororuthenium(II)-doped mesoporous polydopamine nanoparticles covered with an aptamer specific to $\mathrm{HbA}_{1 \mathrm{c}}$ [94]. Interaction of the prepared nanoparticles with $\mathrm{HbA}_{1 \mathrm{c}}$ caused quenching of ruthenium complex electrochemiluminescence. The authors declared the limit of detection to be $0.015 \% \mathrm{HbA}_{1 \mathrm{c}}$ from the total hemoglobin, and the linear range was $0.1-18.5 \%$. Further improvements in optical and electro-optical analytical devices may be based on colorimetric plasmonic sensors [95-97].

Bioanalytical methods and biosensors can work on voltametric principles, as seen in the following cited papers. Shahbazmohammadi and coworkers immobilized fructosyl peptide oxidase with graphene oxide and gold nanoparticles on working electrodes [98]. Fructosyl valyl histidine served as a mimetic of $\mathrm{HbA}_{1 \mathrm{c}}$ and was oxidized by the immobilized enzyme. The amperometric detection provided response in the calibration range 0.1 to $2 \mathrm{mmol} / \mathrm{L}$ with a limit of detection for fructosyl valyl histidine of $0.3 \mu \mathrm{mol} / \mathrm{L}$. In another work, fructosyl amine oxidase immobilized on gold and platinum composite nanoparticles served for $\mathrm{HbA}_{1 \mathrm{c}}$ oxidation and amperometric detection [85]. In another work, a piezoelectric quartz crystal microbalance biosensor was made using iron oxide nanoparticles and a polyclonal antibody specific to $\mathrm{HbA}_{1 \mathrm{c}}$ [99]. The oscillation frequency of the biosensor dropped when $\mathrm{HbA}_{1 \mathrm{c}}$ was caught by the immobilized antibody. The 
assay exerted a limit of detection of $0.045 \mathrm{mg} / \mathrm{mL}$ and it fully correlated to the standard ELISA. The fact that the assay can be finalized in a single step, consisting of the sample application, is a major advantage. A voltametric biosensor-based graphite sheet electrode was constructed by Jaberi and coworkers [100]. The researchers covered the graphite sheet with a nanocomposite composed of reduced graphene oxide and gold and further with a DNA aptamer specific to $\mathrm{HbA}_{1 \mathrm{c}}$. The interaction with $\mathrm{HbA}_{1 \mathrm{c}}$ caused a change in voltametric sensitivity to Prussian blue presented in the ambient solution, and differential pulse voltammetry served for the response measurement. The biosensor had a linear range of $1 \mathrm{nmol} / \mathrm{L}-13.8 \mu \mathrm{mol} / \mathrm{L}$, a sensitivity of $269 \mu \mathrm{A} / \mathrm{cm}^{2}$ and a limit of detection of $1 \mathrm{nmol} / \mathrm{L}$ for the $\mathrm{HbA}_{1 \mathrm{c}}$ assay.

Affinity interactions with $\mathrm{HbA}_{1 \mathrm{c}}$ can be based on simpler molecules than the aforementioned antibodies and aptamers. Derivatives of boronic acid appear to be suitable reagents for this interaction [101-104]. An electrochemical sensor system for $\mathrm{HbA}_{1 \mathrm{c}}$ detection using boronic acid was proposed in the work of Wang and coworkers [105]. The researchers prepared gold nano-flowers modified by 4-mercaptophenylboronic acid and the whole complex was located on graphite screen-printed electrodes. $\mathrm{HbA}_{1 \mathrm{c}}$ was caught on the 4-mercaptophenylboronic acid and then catalyzed the reduction of hydrogen peroxide, which was recorded by cyclic voltammetry. Gold nanoflowers improved the transport of electrons from the reaction to the electrode. The assay exerted a linear dynamic range of $5-1000 \mu \mathrm{g} / \mathrm{mL}$ representing $2-20 \%$ of $\mathrm{HbA}_{1 \mathrm{c}}$ for an assay lasting $65 \mathrm{~min}$. Boronic acid can serve as a matrix for the imprinting of $\mathrm{HbA}_{1 \mathrm{c}}$ relative to non-glycated hemoglobin and for making a molecularly-imprinted polymer, as described in the work by Pandey and coworkers [106]. A molecularly imprinted polymer was made from aminophenylboronic acid with poly-rhodamine $b$ nanocubes and deposited on carbon paste-coated aluminum foil by electropolymerization. The interaction of $\mathrm{HbA}_{1 \mathrm{c}}$ (relative to non-glycated hemoglobin) with the sensor changed the voltametric properties of the electrode, which was measured. The sensor provided a limit of detection equal to $0.08 \mathrm{ng} / \mathrm{mL}$ for the non-glycated hemoglobin and $0.09 \mathrm{ng} / \mathrm{mL}$ for the $\mathrm{HbA}_{1 \mathrm{c}}$. A survey of selected aforementioned methods is presented in Table 2.

Table 2. Biosensors and bioassays for $\mathrm{HbA}_{1 \mathrm{c}}$ measurement.

\begin{tabular}{|c|c|c|c|c|}
\hline Principle of Assay & $\begin{array}{l}\text { Recognition Parts in } \\
\text { the Assay }\end{array}$ & Specifications & Limit of Detection & References \\
\hline Surface plasmon resonance & aptamer & $\begin{array}{c}\text { sensitivity } 1.06 \times 10^{-3} \\
\mathrm{RU} / \mathrm{nmol} / \mathrm{L}\end{array}$ & $\begin{array}{l}\text { limit of detection } \\
2.55 \mathrm{nmol} / \mathrm{L}\end{array}$ & [91] \\
\hline Surface plasmon resonance & aptamer & $\begin{array}{l}\text { linear dynamic range } \\
18-147 \mathrm{nmol} / \mathrm{L}\end{array}$ & $\begin{array}{l}\text { limit of detection } \\
1 \mathrm{nmol} / \mathrm{L}\end{array}$ & [92] \\
\hline $\begin{array}{l}\text { Measuring of photocurrent } \\
\text { using bacteriorhodopsin and } \\
\text { aptamer embedded membrane, } \\
\text { interaction with analyte causes } \\
\text { reduction of photocurrent }\end{array}$ & aptamer & $\begin{array}{c}\text { dynamic range } \\
0.1-100 \mu \mathrm{g} / \mathrm{mL} \text { in a } \\
15 \mathrm{~min} \text { measuring cycle }\end{array}$ & $\begin{array}{l}\text { limit of detection under } \\
0.1 \mu \mathrm{g} / \mathrm{mL}\end{array}$ & [93] \\
\hline $\begin{array}{l}\text { Quenching of ruthenium } \\
\text { complex containing } \\
\text { nanoparticles } \\
\text { electrochemiluminescence in } \\
\text { the presence of } \mathrm{HbA}_{1 \mathrm{c}}\end{array}$ & aptamer & linear range $0.1-18.5 \%$ & $\begin{array}{l}\text { limit of detection } \\
0.015 \% \mathrm{HbA}_{1 \mathrm{c}} \text { from the } \\
\text { total hemoglobin }\end{array}$ & [94] \\
\hline $\begin{array}{l}\text { Enzyme catalyzed oxidation of } \\
\text { fructosyl valyl histidine as a } \\
\text { mimetic of } \mathrm{HbA}_{1 \mathrm{c}} \\
\text { amperometric } \\
\text { detection followed }\end{array}$ & fructosyl peptide oxidase & $\begin{array}{l}\text { calibration range } 0.1 \text { to } \\
22 \mathrm{mmol} / \mathrm{L}\end{array}$ & $\begin{array}{l}\text { limit of detection } \\
0.3 \mu \mathrm{mol} / \mathrm{L}\end{array}$ & [98] \\
\hline
\end{tabular}


Table 2. Cont

\begin{tabular}{|c|c|c|c|c|}
\hline Principle of Assay & $\begin{array}{c}\text { Recognition Parts in } \\
\text { the Assay }\end{array}$ & Specifications & Limit of Detection & References \\
\hline $\begin{array}{l}\text { Quartz crystal microbalance } \\
\text { biosensor with immobilized } \\
\text { antibody directly interacted } \\
\text { with } \mathrm{HbA}_{1 \mathrm{c}} \text {, drop in oscillation } \\
\text { frequency followed }\end{array}$ & polyclonal antibody & - & $\begin{array}{l}\text { limit of detection } 0.045 \\
\mathrm{mg} / \mathrm{mL}\end{array}$ & [99] \\
\hline $\begin{array}{l}\text { Voltametric biosensor with } \\
\text { immobilized aptamer, } \\
\text { interaction with } \mathrm{HbA}_{1 \mathrm{c}} \text { caused } \\
\text { change in sensitivity to } \\
\text { Prussian blue in } \\
\text { ambient solution }\end{array}$ & aptamer & $\begin{array}{c}\text { linear range } \\
1 \mathrm{nmol} / \mathrm{L}-13.8 \mu \mathrm{mol} / \mathrm{L}, \\
\text { sensitivity } 269 \mu \mathrm{A} / \mathrm{cm}^{2}\end{array}$ & $\begin{array}{l}\text { limit of detection } \\
1 \mathrm{nmol} / \mathrm{L}\end{array}$ & [100] \\
\hline $\begin{array}{l}\mathrm{HbA}_{1 \mathrm{c}} \text { was caught by boronic } \\
\text { acid and then catalyzed } \\
\text { reduction of hydrogen } \\
\text { peroxide, which was recorded } \\
\text { by cyclic voltammetry }\end{array}$ & $\begin{array}{l}\text { gold nanoparticles } \\
\text { covered with 4- } \\
\text { mercaptophenylboronic } \\
\text { acid }\end{array}$ & $\begin{array}{l}\text { linear dynamic range } \\
5-1000 \mu \mathrm{g} / \mathrm{mL} \\
\text { respective } 2-20 \% \text {, assay } \\
\text { lasting } 65 \mathrm{~min}\end{array}$ & - & [105] \\
\hline $\begin{array}{l}\text { Interaction of non-glycated } \\
\text { hemoglobin respective to } \\
\mathrm{Hb}_{1 \mathrm{c}} \text { with molecularly } \\
\text { imprinted polymer caused } \\
\text { change in voltametric } \\
\text { characteristics }\end{array}$ & $\begin{array}{l}\text { molecularly imprinted } \\
\text { polymer based on } \\
\text { boronic acid }\end{array}$ & - & $\begin{array}{l}\text { limit of detection equal } \\
0.08 \mathrm{ng} / \mathrm{mL} \text { for the } \\
\text { non-glycated } \\
\text { hemoglobin, } \\
0.09 \mathrm{ng} / \mathrm{mL} \text { for the } \\
\mathrm{HbA}_{1 \mathrm{c}}\end{array}$ & [106] \\
\hline
\end{tabular}

Real point-of-care assays for the detection $\mathrm{HbA}_{1 \mathrm{c}}$ by small portable devices appear to be a possibility in the coming years. The current research on biosensors and similar bioassays appears to be promising. Even though many of the assays proposed in the literature are not suitable for mass commercial production because their parts (specific nanoparticles or handmade aptamers, for instance) are not available in the market, this situation may change in the future. Research and development on $\mathrm{HbA}_{1 \mathrm{c}}$ point-of-care tests can be further intensified when their marketing is supported by health insurance companies, as with standard glucose tests, which are provided or paid out to diabetic patients in some countries.

\section{Conclusions}

Glycated hemoglobin is an important biochemical marker that provides more reliable clues for diabetes mellitus diagnosis than glucose and glycemia measurements. Compared to the glucose assay, the point-of-care determination of $\mathrm{HbA}_{1 \mathrm{c}}$ has not been successfully commercialized and new measuring devices are being extensively investigated. The practical impact of the current research is expected to be seen in the future, when the point-of-care assays for $\mathrm{HbA}_{1 \mathrm{c}}$ may become a relevant analytical tool, making the accurate diagnosis of diabetes mellitus more available in future clinical practice. Future research should be focused on the development of simple methods for $\mathrm{HbA}_{1 \mathrm{c}}$ quantitative assays based on portable detectors.

Funding: This research was funded by a long-term organization development plan (Faculty of Military Health Sciences, University of Defense, Czech Republic).

Institutional Review Board Statement: Not applicable.

Informed Consent Statement: Not applicable.

Data Availability Statement: All data are provided in this work. 
Acknowledgments: In this section, you can acknowledge any support given which is not covered by the author contribution or funding sections. This may include administrative and technical support, or donations in kind (e.g., materials used for experiments).

Conflicts of Interest: The author declares no conflict of interest.

\section{References}

1. Islam, T.; Hasan, M.M.; Awal, A.; Nurunnabi, M.; Ahammad, A.J.S. Metal nanoparticles for electrochemical sensing: Progress and challenges in the clinical transition of point-of-care testing. Molecules 2020, 25, 5787. [CrossRef]

2. Masumi, L.; Fakhim, H.; Vaezi, A.; Pourhassan-Moghaddam, M.; Ebrahimi-Kalan, A.; Zarghami, N. Strategies for isothermal amplification of nucleic acids: Are they ready to be applied in point of care diagnosis of mycosis? Biointerface Res. Appl. Chem. 2021, 11, 10559-10571.

3. Ernst, E.; Wolfe, P.; Stahura, C.; Edwards, K.A. Technical considerations to development of serological tests for sars-cov-2. Talanta 2021, 224, 121883. [CrossRef]

4. Chaouch, M. Loop-mediated isothermal amplification (lamp): An effective molecular point-of-care technique for the rapid diagnosis of coronavirus sars-cov-2. Rev. Med. Virol. 2021, e2215. [CrossRef]

5. Lingervelder, D.; Koffijberg, H.; Kusters, R.; Ijzerman, M.J. Health economic evidence of point-of-care testing: A systematic review. PharmacoEcon. Open 2021. [CrossRef] [PubMed]

6. Rezaei, M.; Bazaz, S.R.; Zhand, S.; Sayyadi, N.; Jin, D.; Stewart, M.P.; Warkiani, M.E. Point of care diagnostics in the age of covid-19. Diagnostics 2021, 11, 9. [CrossRef] [PubMed]

7. Apple, F.S.; Fantz, C.R.; Collinson, P.O.; Car, I.C.C.A. Implementation of high-sensitivity and point-of-care cardiac troponin assays into practice: Some different thoughts. Clin. Chem. 2021, 67, 70-78. [CrossRef] [PubMed]

8. Price, C.P.; Fay, M.; Hopstaken, R.M. Point-of-care testing for d-dimer in the diagnosis of venous thromboembolism in primary care: A narrative review. Cardiol. Ther. 2021. [CrossRef]

9. Bomholt, T.; Adrian, T.; Norgaard, K.; Ranjan, A.G.; Almdal, T.; Larsson, A.; Vadstrup, M.; Rix, M.; Feldt-Rasmussen, B.; Hornum, $\mathrm{M}$. The use of hba1c, glycated albumin and continuous glucose monitoring to assess glucose control in the chronic kidney disease population including dialysis. Nephron 2021, 145, 14-19. [CrossRef]

10. Kaur, G.; Lakshmi, P.V.M.; Rastogi, A.; Bhansali, A.; Jain, S.; Teerawattananon, Y.; Bano, H.; Prinja, S. Diagnostic accuracy of tests for type 2 diabetes and prediabetes: A systematic review and meta-analysis. PLoS ONE 2020, 15, e0242415. [CrossRef]

11. Amaefule, C.E.; Sasitharan, A.; Kalra, P.; Iliodromoti, S.; Huda, M.S.B.; Rogozinska, E.; Zamora, J.; Thangaratinam, S. The accuracy of haemoglobin a1c as a screening and diagnostic test for gestational diabetes: A systematic review and meta-analysis of test accuracy studies. Curr. Opin. Obstet. Gynecol. 2020, 32, 322-334. [CrossRef]

12. Sølvik, U.; Røraas, T.; Christensen, N.G.; Sandberg, S. Diagnosing diabetes mellitus: Performance of hemoglobin a1c point-of-care instruments in general practice offices. Clin. Chem. 2013, 59, 1790-1801. [CrossRef]

13. Hirst, J.A.; McLellan, J.H.; Price, C.P.; English, E.; Feakins, B.G.; Stevens, R.J.; Farmer, A.J. Performance of point-of-care hba1c test devices: Implications for use in clinical practice-A systematic review and meta-analysis. Clin. Chem. Lab. Med. 2017, 55, 167-180. [CrossRef]

14. Spaeth, B.A.; Shephard, M.D.S.; Schatz, S. Point-of-care testing for haemoglobin a1c in remote australian indigenous communities improves timeliness of diabetes care. Rural Remote Health 2014, 14, 2849. [PubMed]

15. Bergmann, K.; Sypniewska, G. The influence of sample freezing at $-80^{\circ} \mathrm{C}$ for $2-12$ weeks on glycated haemoglobin (hba(1c)) concentration assayed by hplc method on bio-rad d-10 ${ }^{\circledR}$ auto analyzer. Biochem. Med. 2016, 26, 346-352. [CrossRef] [PubMed]

16. Thorpe, S.R.; Baynes, J.W. Maillard reaction products in tissue proteins: New products and new perspectives. Amino Acids 2003, 25, 275-281. [CrossRef]

17. Singh, V.P.; Bali, A.; Singh, N.; Jaggi, A.S. Advanced glycation end products and diabetic complications. Korean J. Physiol. Pharmacol. 2014, 18, 1-14. [CrossRef]

18. Takahashi, S.; Uchino, H.; Shimizu, T.; Kanazawa, A.; Tamura, Y.; Sakai, K.; Watada, H.; Hirose, T.; Kawamori, R.; Tanaka, Y. Comparison of glycated albumin (ga) and glycated hemoglobin (hba1c) in type 2 diabetic patients: Usefulness of ga for evaluation of short-term changes in glycemic control. Endocr. J. 2007, 54, 139-144. [CrossRef]

19. Buffarini, R.; Restrepo-Méndez, M.C.; Silveira, V.M.; Miranda, J.J.; Gonçalves, H.D.; Oliveira, I.O.; Horta, B.L.; Gigante, D.P.; Menezes, A.M.; Assunção, M.C.F. Distribution of glycated haemoglobin according to early-life and contemporary characteristics in adolescents and adults without diabetes: The 1982 and 1993 pelotas birth cohorts. PLoS ONE 2016, 11, e0162614. [CrossRef]

20. Winston, A.P. Eating disorders and diabetes. Curr. Diabetes Rep. 2020, 20, 32. [CrossRef]

21. Katwal, P.C.; Jirjees, S.; Htun, Z.M.; Aldawudi, I.; Khan, S. The effect of anemia and the goal of optimal hba1c control in diabetes and non-diabetes. Cureus 2020, 12, e8431.

22. Kohzuma, T.; Yamamoto, T.; Uematsu, Y.; Shihabi, Z.K.; Freedman, B.I. Basic performance of an enzymatic method for glycated albumin and reference range determination. J. Diabetes Sci. Technol. 2011, 5, 1455-1462. [CrossRef]

23. Yoshiuchi, K.; Matsuhisa, M.; Katakami, N.; Nakatani, Y.; Sakamoto, K.; Matsuoka, T.; Umayahara, Y.; Kosugi, K.; Kaneto, H.; Yamasaki, Y.; et al. Glycated albumin is a better indicator for glucose excursion than glycated hemoglobin in type 1 and type 2 diabetes. Endocr. J. 2008, 55, 503-507. [CrossRef] 
24. Wang, Y.; Yu, H.; Shi, X.; Luo, Z.; Lin, D.; Huang, M. Structural mechanism of ring-opening reaction of glucose by human serum albumin. J. Biol. Chem. 2013, 288, 15980-15987. [CrossRef] [PubMed]

25. Kouzuma, T.; Usami, T.; Yamakoshi, M.; Takahashi, M.; Imamura, S. An enzymatic method for the measurement of glycated albumin in biological samples. Clin. Chim. Acta 2002, 324, 61-71. [CrossRef]

26. Roohk, H.V.; Zaidi, A.R. A review of glycated albumin as an intermediate glycation index for controlling diabetes. J. Diabetes Sci. Technol. 2008, 2, 1114-1121. [CrossRef] [PubMed]

27. Koga, M.; Kasayama, S. Clinical impact of glycated albumin as another glycemic control marker. Endocr. J. 2010, 57, 751-762. [CrossRef] [PubMed]

28. Watala, C.; Gwoȧdzinski, K.; Małek, M. Direct evidence for the alterations in protein structure and conformation upon in vitro nonenzymatic glycosylation. Int. J. Biochem. 1992, 24, 1295-1302. [CrossRef]

29. Syamala Kiran, M.; Itoh, T.; Yoshida, K.-I.; Kawashima, N.; Biju, V.; Ishikawa, M. Selective detection of hba1c using surface enhanced resonance raman spectroscopy. Anal. Chem. 2010, 82, 1342-1348. [CrossRef]

30. Bakhti, M.; Habibi-Rezaei, M.; Moosavi-Movahedi, A.; Khazaei, M. Consequential alterations in haemoglobin structure upon glycation with fructose: Prevention by acetylsalicylic acid. J. Biochem. 2007, 141, 827-833. [CrossRef] [PubMed]

31. McDonald, M.J.; Bleichman, M.; Bunn, H.; Noble, R.W. Functional properties of the glycosylated minor components of human adult hemoglobin. J. Biol. Chem. 1979, 254, 702-707. [CrossRef]

32. Zhang, X.; Medzihradszky, K.F.; Cunningham, J.; Lee, P.D.K.; Rognerud, C.L.; Ou, C.-N.; Harmatz, P.; Witkowska, H.E Characterization of glycated hemoglobin in diabetic patients: Usefulness of electrospray mass spectrometry in monitoring the extent and distribution of glycation. J. Chromatogr. B Biomed. Sci. Appl. 2001, 759, 1-15. [CrossRef]

33. Ali, S.; Rao, N.I.L. Correlation of serum fluorescence of advanced glycation end products with diabetes duration and glycemic control in type 2 diabetic patients. Biomed. Res. Ther. 2020, 7, 3933-3938. [CrossRef]

34. Gonzalez-Viveros, N.; Castro-Ramos, J.; Gomez-Gil, P.; Cerecedo-Nunez, H.H. Characterization of glycated hemoglobin based on raman spectroscopy and artificial neural networks. Spectroc. Acta Part. A Mol. Biomol. Spectr. 2021, 247, 119077. [CrossRef]

35. Szkudlarek, A.; Sułkowska, A.; Maciążek-Jurczyk, M.; Chudzik, M.; Równicka-Zubik, J. Effects of non-enzymatic glycation in human serum albumin. Spectroscopic analysis. Spectrochim. Acta Part A Mol. Biomol. Spectrosc. 2016, 152, 645-653. [CrossRef]

36. Keith, N.; Parodi, A.J.; Caramelo, J.J. Glycoprotein tertiary and quaternary structures are monitored by the same quality control mechanism. J. Biol. Chem. 2005, 280, 18138-18141. [CrossRef]

37. Shanbhag, V.P.; Axelsson, C.-G. Hydrophobic interaction determined by partition in aqueous two-phase systems. Eur. J. Biochem. 1975, 60, 17-22. [CrossRef]

38. Zaslavsky, B.Y.; Uversky, V.N.; Chait, A. Analytical applications of partitioning in aqueous two-phase systems: Exploring protein structural changes and protein-partner interactions in vitro and in vivo by solvent interaction analysis method. Biochim. Biophys. Acta (BBA) Proteins Proteom. 2016, 1864, 622-644. [CrossRef]

39. Chait, A.; Zaslavsky, B.Y. Method for Evaluation of the Ratio of Amounts of Biomolecules or Their Sub-Populations in a Mixture. U.S. Patent No. 6,136,960, 24 October 2000.

40. Bancks, M.P.; Odegaard, A.O.; Koh, W.P.; Yuan, J.M.; Gross, M.D.; Pereira, M.A. Glycated hemoglobin and incident type 2 diabetes in singaporean chinese adults: The singapore chinese health study. PLoS ONE 2015, 10, e0119884. [CrossRef] [PubMed]

41. Appel, E.V.R.; Moltke, I.; Jorgensen, M.E.; Bjerregaard, P.; Linneberg, A.; Pedersen, O.; Albrechtsen, A.; Hansen, T.; Grarup, N. Genetic determinants of glycated hemoglobin levels in the greenlandic inuit population. Eur. J. Hum. Genet. 2018, 26, 868-875. [CrossRef]

42. Bryśkiewicz, M.E.; Majkowska, L. Glycated hemoglobin (hba1c) as a standard diagnostic criterium for diabetes? Pol. Merkur Lek. 2011, 30, 150-154.

43. Ito, M.; Sano, K.; Koga, M. 3 cases of variant hemoglobin hb a2-niigata detected by falsely high hba1c values. Clin. Chim. Acta 2020, 510, 656-658. [CrossRef]

44. Okamoto, T.; Shima, H.; Noma, Y.; Komatsu, M.; Azuma, H.; Miya, K.; Tashiro, M.; Inoue, T.; Masaki, C.; Tada, H.; et al. Hereditary spherocytosis diagnosed with extremely low glycated hemoglobin compared to plasma glucose levels. Diabetol. Int. 2021. [CrossRef]

45. Kulkarni, J.D.; Shivashanker, S. Incidental detection of hemoglobin variants during evaluation of hba1c. Indian J. Clin. Biochem. 2021. [CrossRef]

46. Tran, T.T.H.; Jeong, J.S. Optimization of microwave-assisted method for accelerated glycated hemoglobin quantification from amino acids to proteins. Mass Spectrom. Lett. 2017, 8, 53-58.

47. Chen, H.J.C.; Teng, Y.C. Stability of glyoxal- and methylglyoxal-modified hemoglobin on dried blood spot cards as analyzed by nanoflow liquid chromatography tandem mass spectrometry. J. Food Drug Anal. 2019, 27, 526-530. [CrossRef]

48. Tran, T.T.H.; Lim, J.; Kim, J.; Kwon, H.J.; Kwon, G.C.; Jeong, J.S. Fully international system of units-traceable glycated hemoglobin quantification using two stages of isotope-dilution high-performance liquid chromatography-tandem mass spectrometry. $J$. Chromatogr. A 2017, 1513, 183-193. [CrossRef]

49. Xu, A.P.; Wang, Y.J.; Li, J.; Xie, W.J.; Chen, W.D.; Ji, L. Detection of hb phnom penh by matrix-assisted laser desorption/ionization time-of-flight (maldi-tof) mass spectrometry during the measurement of glycated hemoglobin. Clin. Chem. Lab. Med. 2020, 58, E233-E235. [CrossRef] [PubMed] 
50. Gilani, M.; Aamir, M.; Akram, A.; Haroon, Z.H.; Ijaz, A.; Khadim, M.T. Comparison of turbidimetric inhibition immunoassay, high-performance liquid chromatography, and capillary electrophoresis methods for glycated hemoglobin determination. Lab. Med. 2020, 51, 579-584. [CrossRef]

51. Xu, A.P.; Chen, W.D.; Xie, W.J.; Wang, Y.J.; Ji, L. Hemoglobin variants in southern china: Results obtained during the measurement of glycated hemoglobin in a large population. Clin. Chem. Lab. Med. 2021, 59, 227-232. [CrossRef]

52. Stolz, A.; Hedeland, Y.; Salzer, L.; Romer, J.; Heiene, R.; Leclercq, L.; Cottet, H.; Bergquist, J.; Neususs, C. Capillary zone electrophoresis-top-down tandem mass spectrometry for in-depth characterization of hemoglobin proteoforms in clinical and veterinary samples. Anal. Chem. 2020, 92, 10531-10539. [CrossRef]

53. Pullon, B.M. An evaluation of glycated haemoglobin eluting in zone 10 on capillary zone electrophoresis. J. Lab. Med. 2020, 44, 55-58. [CrossRef]

54. Vargas, M.G.; Gomez, B.J.P.; Lorenti, F.E.V.; Condo, G.M.A.; Neira, E.I.R.; Veron, D.; Veron, M.F.; Cercado, A.G.; Bahar, B.; Tufro, A. Assessment of two glycated hemoglobin immunoassays. Endocrinol. Diabetes Nutr. 2020, 67, 297-303. [CrossRef]

55. Edriss, H.; Molehin, A.J.; Selvan, K.; Gavidia, R.; Patel, P.U.; Nugent, K. Advanced glycation end products and glycosaminoglycans in patients with diabetic ketoacidosis. J. Investig. Med. 2020, 68, 738-742. [CrossRef] [PubMed]

56. Yasun, E.; Trusty, T.; Abolhosn, R.W.; Clarke, N.J.; Mezic, I. Electrokinetic mixing for improving the kinetics of an hba1c immunoassay. Sci. Rep. 2019, 9, 19885. [CrossRef] [PubMed]

57. Movsas, T.Z.; Muthusamy, A. Feasibility of neonatal haemoglobin a1c as a biomarker for retinopathy of prematurity. Biomarkers 2020, 25, 468-473. [CrossRef] [PubMed]

58. Tang, L.; Chang, S.J.; Chen, C.J.; Liu, J.T. Non-invasive blood glucose monitoring technology: A review. Sensors 2020, $20,6925$. [CrossRef] [PubMed]

59. Juska, V.B.; Pemble, M.E. A critical review of electrochemical glucose sensing: Evolution of biosensor platforms based on advanced nanosystems. Sensors 2020, 20, 6013. [CrossRef] [PubMed]

60. Thatikayala, D.; Ponnamma, D.; Sadasivuni, K.K.; Cabibihan, J.J.; Al-Ali, A.K.; Malik, R.A.; Min, B. Progress of advanced nanomaterials in the non-enzymatic electrochemical sensing of glucose and h2o2. Biosensors 2020, 10, 151. [CrossRef] [PubMed]

61. Huang, J.M.; Zhang, Y.; Wu, J. Review of non-invasive continuous glucose monitoring based on impedance spectroscopy. Sens. Actuator A Phys. 2020, 311, 112103. [CrossRef]

62. Mandpe, P.; Prabhakar, B.; Gupta, H.; Shende, P. Glucose oxidase-based biosensor for glucose detection from biological fluids. Sens. Rev. 2020, 40, 497-511. [CrossRef]

63. He, W.J.; Huang, Y.X.; Wu, J. Enzyme-free glucose biosensors based on mos2 nanocomposites. Nanoscale Res. Lett. 2020, 15, 60. [CrossRef] [PubMed]

64. Lisi, F.; Peterson, J.R.; Gooding, J.J. The application of personal glucose meters as universal point-of-care diagnostic tools. Biosens. Bioelectron. 2020, 148, 111835. [CrossRef] [PubMed]

65. Dziergowska, K.; Labowska, M.B.; Gasior-Glogowska, M.; Kmiecik, B.; Detyna, J. Modern noninvasive methods for monitoring glucose levels in patients: A review. Bio-Algorithms Med. Syst. 2019, 15, 20190052. [CrossRef]

66. Scognamiglio, V.; Arduini, F. The technology tree in the design of glucose biosensors. Trac-Trends Anal. Chem. 2019, 120, 115642. [CrossRef]

67. Zhang, T.; Wang, H.B.; Zhong, Z.T.; Li, C.Q.; Chen, W.; Liu, B.; Zhao, Y.D. A smartphone-based rapid quantitative detection platform for lateral flow strip of human chorionic gonadotropin with optimized image algorithm. Microchem. J. 2020, 157, 105038. [CrossRef]

68. Sathishkumar, N.; Toley, B.J. Development of an experimental method to overcome the hook effect in sandwich-type lateral flow immunoassays guided by computational modelling. Sens. Actuator B Chem. 2020, 324, 128756. [CrossRef]

69. Kasetsirikul, S.; Shiddiky, M.J.A.; Nguyen, N.T. Challenges and perspectives in the development of paper-based lateral flow assays. Microfluid. Nanofluid. 2020, 24, 17. [CrossRef]

70. Ang, S.H.; Rambeli, M.; Thevarajah, T.M.; Alias, Y.B.; Khor, S.M. Quantitative, single-step dual measurement of hemoglobin a1c and total hemoglobin in human whole blood using a gold sandwich immunochromatographic assay for personalized medicine. Biosens. Bioelectron. 2016, 78, 187-193. [CrossRef]

71. Khlebtsov, B.; Khlebtsov, N. Surface-enhanced raman scattering-based lateral-flow immunoassay. Nanomaterials 2020, 10, 2228. [CrossRef]

72. Li, H.; Wang, D.; Tang, X.Q.; Zhang, W.; Zhang, Q.; Li, P.W. Time-resolved fluorescence immunochromatography assay (trfica) for aflatoxin: Aiming at increasing strip method sensitivity. Front. Microbiol. 2020, 11, 676. [CrossRef] [PubMed]

73. Mak, W.C.; Beni, V.; Turner, A.P.F. Lateral-flow technology: From visual to instrumental. Trac-Trends Anal. Chem. 2016, 79, 297-305. [CrossRef]

74. Hsieh, H.V.; Dantzler, J.L.; Weigl, B.H. Analytical tools to improve optimization procedures for lateral flow assays. Diagnostics 2017, 7, 29. [CrossRef] [PubMed]

75. Urusov, A.E.; Zherdev, A.V.; Dzantiev, B.B. Towards lateral flow quantitative assays: Detection approaches. Biosensors $2019,9,89$. [CrossRef]

76. Kumar, S.; Nehra, M.; Khurana, S.; Dilbaghi, N.; Kumar, V.; Kaushik, A.; Kim, K.H. Aspects of point-of-care diagnostics for personalized health wellness. Int. J. Nanomed. 2021, 16, 383-402. [CrossRef] [PubMed] 
77. Sardini, E.; Serpelloni, M.; Tonello, S. Printed electrochemical biosensors: Opportunities and metrological challenges. Biosensors 2020, 10, 166. [CrossRef] [PubMed]

78. Mejia-Salazar, J.R.; Cruz, K.R.; Vasques, E.M.M.; de Oliveira, O.N. Microfluidic point-of-care devices: New trends and future prospects for ehealth diagnostics. Sensors 2020, 20, 1951. [CrossRef]

79. Konwar, A.N.; Borse, V. Current status of point-of-care diagnostic devices in the indian healthcare system with an update on covid-19 pandemic. Sens. Intern. 2021. [CrossRef]

80. Sharma, P.; Panchal, A.; Yadav, N.; Narang, J. Analytical techniques for the detection of glycated haemoglobin underlining the sensors. Int. J. Biol. Macromol. 2020, 155, 685-696. [CrossRef]

81. Ahmadi, A.; Kabiri, S.; Omidfar, K. Advances in hba1c biosensor development based on field effect transistors: A review. IEEE Sens. J. 2020, 20, 8912-8921. [CrossRef]

82. Mulder, D.W.; Phiri, M.M.; Vorster, B.C. Gold nanostar colorimetric detection of fructosyl valine as a potential future point of care biosensor candidate for glycated haemoglobin detection. Biosensors 2019, 9, 100. [CrossRef]

83. Jain, U.; Chauhan, N. Glycated hemoglobin detection with electrochemical sensing amplified by gold nanoparticles embedded n-doped graphene nanosheet. Biosens. Bioelectron. 2017, 89, 578-584. [CrossRef] [PubMed]

84. Eissa, S.; Zourob, M. Aptamer-based label-free electrochemical biosensor array for the detection of total and glycated hemoglobin in human whole blood. Sci. Rep. 2017, 7, 1016. [CrossRef]

85. Jain, U.; Gupta, S.; Chauhan, N. Detection of glycated hemoglobin with voltammetric sensing amplified by 3d-structured nanocomposites. Int. J. Biol. Macromol. 2017, 101, 896-903. [CrossRef]

86. Lin, H.; Yi, J. Current status of hba1c biosensors. Sensors 2017, 17, 1798. [CrossRef]

87. Li, M.; Zhao, W.J.; Tian, L.L.; Li, H.F.; Fan, B. Fabrication of biosensor for selective electrochemical determination of glycated hemoglobin. Int. J. Electrochem. Sci. 2017, 12, 8411-8420. [CrossRef]

88. Tsai, S.A.; Tang, J.Y.; Wang, M.H.; Jang, L.S. Impedance measurement system for automatic determination of glycated hemoglobin. Rev. Sci. Instrum. 2018, 89, 065003. [CrossRef]

89. Yang, J.K.; Lee, H.R.; Hwang, I.J.; Kim, H.I.; Yim, D.; Kim, J.H. Fluorescent 2d ws2 nanosheets bearing chemical affinity elements for the recognition of glycated hemoglobin. Adv. Healthc. Mater. 2018, 7, 1701496. [CrossRef] [PubMed]

90. Tavousi, A.; Rakhshani, M.R.; Mansouri-Birjandi, M.A. High sensitivity label-free refractometer based biosensor applicable to glycated hemoglobin detection in human blood using all-circular photonic crystal ring resonators. Opt. Commun. 2018, 429, 166-174. [CrossRef]

91. Sun, D.P.; Wu, Y.; Chang, S.J.; Chen, C.J.; Liu, J.T. Investigation of the recognition interaction between glycated hemoglobin and its aptamer by using surface plasmon resonance. Talanta 2021, 222, 121466. [CrossRef]

92. Zhang, C.G.; Chang, S.J.; Settu, K.; Chen, C.J.; Liu, J.T. High-sensitivity glycated hemoglobin (hba1c) aptasensor in rapidprototyping surface plasmon resonance. Sens. Actuator B Chem. 2019, 279, 267-273. [CrossRef]

93. Lin, Y.C.; Lin, C.Y.; Chen, H.M.; Kuo, L.P.; Hsieh, C.E.; Wang, X.H.; Cheng, C.W.; Wu, C.Y.; Chen, Y.S. Direct and label-free determination of human glycated hemoglobin levels using bacteriorhodopsin as the biosensor transducer. Sensors 2020, 20, 7274. [CrossRef]

94. Zhang, P.; Zhang, Y.; Xiong, X.; Lu, Y.; Jia, N.Q. A sensitive electrochemiluminescence immunoassay for glycosylated hemoglobin based on $\mathrm{ru}(\mathrm{bpy})(3)(2+)$ encapsulated mesoporous polydopamine nanoparticles. Sens. Actuator B Chem. 2020, 321, 128626. [CrossRef]

95. Mauriz, E. Clinical applications of visual plasmonic colorimetric sensing. Sensors 2020, 20, 6214. [CrossRef]

96. Reinhard, I.; Miller, K.; Diepenheim, G.; Cantrell, K.; Hall, W.P. Nanoparticle design rules for colorimetric plasmonic sensors. ACS Appl. Nano Mater. 2020, 3, 4342-4350. [CrossRef]

97. Mejía-Salazar, J.R.; Oliveira, O.N., Jr. Plasmonic biosensing. Chem. Rev. 2018, 118, 10617-10625. [CrossRef] [PubMed]

98. Shahbazmohammadi, H.; Sardari, S.; Omidinia, E. An amperometric biosensor for specific detection of glycated hemoglobin based on recombinant engineered fructosyl peptide oxidase. Int. J. Biol. Macromol. 2020, 142, 855-865. [CrossRef] [PubMed]

99. Pohanka, M. Qcm biosensor for measurement of glycated hemoglobin. Int. J. Electrochem. Sci. 2019, 14, 11340-11348. [CrossRef]

100. Jaberi, S.Y.S.; Ghaffarinejad, A.; Omidinia, E. An electrochemical paper based nano-genosensor modified with reduced graphene oxide-gold nanostructure for determination of glycated hemoglobin in blood. Anal. Chim. Acta 2019, 1078, 42-52. [CrossRef]

101. Hatamvand, R.; Shams, A.; Mohammadifar, E.; Yari, A.; Adeli, M. Synthesis of boronic acid-functionalized poly(glycerol-oligo gamma-butyrolactone): Nano-networks for efficient electrochemical sensing of biosystems. J. Polym. Sci. Pol. Chem. 2019, 57, 1430-1439. [CrossRef]

102. Li, H.; Huo, W.S.; He, M.L.; Lian, J.; Zhang, S.H.; Gao, Y.H. On-chip determination of glycated hemoglobin with a novel boronic acid copolymer. Sens. Actuator B Chem. 2017, 253, 542-551. [CrossRef]

103. Han, Y.D.; Kim, K.R.; Park, Y.M.; Song, S.Y.; Yang, Y.J.; Lee, K.; Ku, Y.; Yoon, H.C. Boronate-functionalized hydrogel as a novel biosensing interface for the glycated hemoglobin a1c (hba(1c)) based on the competitive binding with signaling glycoprotein. Mater. Sci. Eng. C Mater. Biol. Appl. 2017, 77, 1160-1169. [CrossRef] [PubMed]

104. Li, J.; Bai, Z.M.; Mao, Y.J.; Sun, Q.Q.; Ning, X.H.; Zheng, J.B. Disposable sandwich-type electrochemical sensor for selective detection of glucose based on boronate affinity. Electroanalysis 2017, 29, 2307-2315. [CrossRef] 
105. Wang, X.; Su, J.; Zeng, D.D.; Liu, G.; Liu, L.Z.; Xu, Y.; Wang, C.G.; Liu, X.X.; Wang, L.; Mi, X.Q. Gold nano-flowers (au nfs) modified screen-printed carbon electrode electrochemical biosensor for label-free and quantitative detection of glycated hemoglobin. Talanta 2019, 201, 119-125. [CrossRef]

106. Pandey, I.; Tiwari, J.D. A novel dual imprinted conducting nanocubes based flexible sensor for simultaneous detection of hemoglobin and glycated haemoglobin in gestational diabetes mellitus patients. Sens. Actuator B Chem. 2019, 285, 470-478. [CrossRef] 